\title{
Protection against $P$. aeruginosa with an adenovirus vector containing an OprF epitope in the capsid
}

\author{
Stefan Worgall,,1,2 Anja Krause,,2 Michael Rivara, ${ }^{2}$ Kyung-Kim Hee, ${ }^{2}$ \\ Enrico V. Vintayen, ${ }^{2}$ Neil R. Hackett, ${ }^{2}$ Peter W. Roelvink, ${ }^{3}$ Joseph T. Bruder, ${ }^{3}$ \\ Thomas J. Wickham, ${ }^{3}$ Imre Kovesdi, ${ }^{3}$ and Ronald G. Crystal ${ }^{2}$ \\ 1Department of Pediatrics and 2Department of Genetic Medicine, Weill Medical College of Cornell University, New York, New York, USA. \\ ${ }^{3}$ GenVec Inc., Bethesda, Maryland, USA.
}

\begin{abstract}
Pseudomonas aeruginosa is an important opportunistic pathogen that can cause chronic and often life-threatening infections of the respiratory tract, particularly in individuals with cystic fibrosis (CF). Because infections with $P$. aeruginosa remain the major cause of the high morbidity and mortality of $C F$, a vaccine against $P$. aeruginosa would be very useful for preventing this disorder. The outer membrane protein $F(\mathrm{OprF})$ of $P$. aeruginosa is a promising vaccine candidate and various B cell epitopes within OprF have been identified. Given that adenovirus (Ad) vectors have strong immunogenic potential and can function as adjuvants for genetic vaccines, the present study evaluates the immunogenic and protective properties of a novel replication-deficient Ad vector in which the Ad hexon protein was modified to include a 14-amino acid epitope of $P$. aernginosa OprF (Epi8) in loop 1 of the hypervariable region 5 of the hexon (AdZ.Epi8). Immunization of C57BL/6 mice with AdZ.Epi8 resulted in detectable serum anti- $P$. aernginosa and anti-OprF humoral responses. These responses were haplotype dependent, with higher serum anti-OprF titers in CBA mice than in BALB/c or C57BL/6 mice. AdZ.Epi8 induced Epi8-specific IFN- $\gamma$-positive CD4 and CD8 $\mathrm{T}$ cell responses and resulted in protection against a lethal pulmonary challenge with agar-encapsulated $P$. aeruginosa. Importantly, repeated administration of AdZ.Epi8 resulted in boosting of the anti-OprF humoral and anti-Epi8 cellular response, whereas no boosting effect was present in the response against the transgene $\beta$-galactosidase. These observations suggest that Ad vectors expressing pathogen epitopes in their capsid will protect against an extracellular pathogen and will allow boosting of the epitope-specific humoral response with repeated administration, a strategy that should prove useful in developing Ad vectors as vaccines where humoral immunity will be protective.
\end{abstract}

\section{Introduction}

Pseudomonas aeruginosa is a ubiquitous Gram-negative pathogen that causes respiratory tract infection in individuals with cystic fibrosis (CF) and immunodeficiency (1). Although a variety of antibiotics is available to treat $P$. aeruginosa, chronic respiratory tract colonization with $P$. aeruginosa, with frequent exacerbations, is common in the populations at risk $(1,2)$. Because $P$. aeruginosa is an extracellular bacteria, anti-Pseudomonas humoral immunity should be sufficient to prevent infection, but an effective vaccine against $P$. aeruginosa is not yet available.

Given the concept that adenovirus (Ad) gene transfer vectors readily infect DCs and thus act as immune system adjuvants (3-11), we have focused on the use of Ad as an effective genetic platform for an anti-P. aeruginosa vaccine. The disadvantage of using Ad as a vaccine carrier is that anti-Ad immunity after immunization abrogates the effectiveness of subsequent administration or boosting with an Ad vector of the same serotype due to lack of expression and pre-

Nonstandard abbreviations used: Ad, adenovirus; AdNull, Ad expressing no transgene; AdZ, Ad expressing $\beta$-galactosidase; CF, cystic fibrosis; ELISPOT, enzymelinked immunospot; Epi, epitope of OprF; OprF, outer membrane protein F; pu, particle unit; TBST, $0.05 \%$ Tween 20 in PBS.

Conflict of interest: J. Bruder is an employee of GenVec Inc., and P.W. Roelvink, T.J. Wickham, and I. Kovesdi were formerly employees of GenVec Inc.; all of these authors have equity in GenVec Inc.

Citation for this article: J. Clin. Invest. 115:1281-1289 (2005). doi:10.1172/JCI200523135. sentation of the antigen encoded by the transgene $(5,12-16)$. One strategy to circumvent this challenge is based on the knowledge that anti-Ad capsid immune responses are augmented by repeated administration $(12,16,17)$, and thus immune responses against epitopes that are part of the Ad capsid should be augmented with repeated administration and would thus allow boosting. Because epitope-based vaccine approaches usually need potent adjuvants to be effective (18), incorporation of an immunogenic peptide into the Ad capsid proteins theoretically would have the advantage of being processed as the other capsid proteins via the exogenous pathway and should result in a humoral response similar to that elicited by the capsid proteins $(16,17,19,20)$.

Based on those considerations, the present study analyzes a novel Ad-based vaccine with epitopes derived from $P$. aeruginosa outer membrane protein $\mathrm{F}(\mathrm{OprF})$ incorporated into the hexon. OprF has been shown to be immunogenic in laboratory animals and humans, and the sequence of OprF suggests that there are several extracellular loops that serve as good B cell epitopes (Figure 1) (21-29). The Ad hexon is the most abundant immunogenic of the Ad capsid proteins (30-33). After genetic insertion of OprF epitopes into one of the external loops of the hexon, each Ad carries 720 epitopes (30). Because the OprF epitopes are incorporated into the Ad capsid, it should be possible to enhance anti-P. aeruginosa humoral immunity by repeated administration of the Ad vaccine. The data demonstrate that immunization with an Ad incorporating $P$. aeruginosa OprF epitopes into the Ad capsid induces antibodies against $P$. aeruginosa 


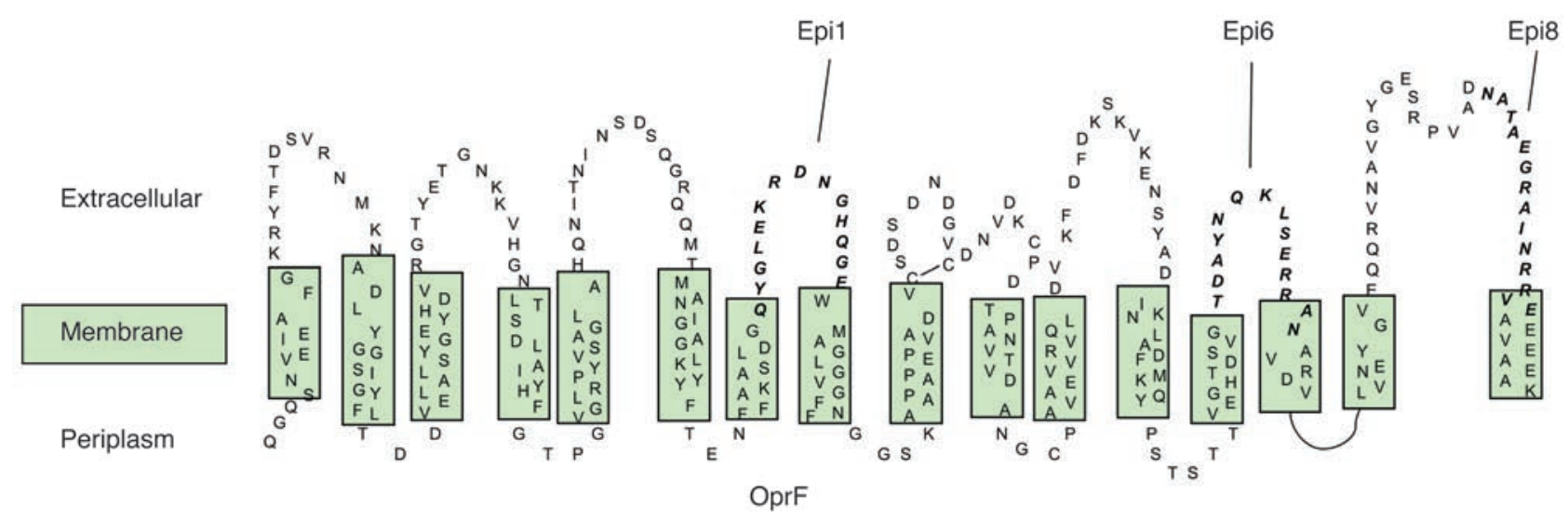

Figure 1

Schematic of the P. aeruginosa outer membrane protein OprF. The amino acid sequences of OprF epitopes Epi1, Epi6, and Epi8, which were incorporated into the Ad hexon protein of the Ad vectors used in the present study, are shown in bold (figure modified with permission from ref. 21).

in an MHC-dependent fashion, elicits epitope-specific CD4 and CD8 $\mathrm{T}$ cell responses, protects against a lethal pulmonary challenge with Pseudomonas, and, most importantly, boosted the anti-OprF immune response with repeated administration.

\section{Results}

Humoral immune response containing OprF epitope. To assess the humoral response against $P$. aeruginosa after immunization with vectors consisting of Ad expressing $\beta$-galactosidase $(\mathrm{AdZ})$ plus epitope 1, 6, or 8 (Epi1, Epi6, or Epi8) of OprF (the AdZ.Epi1, AdZ. Epi6, and AdZ.Epi8 vectors, respectively), we determined the serum IgG responses against the laboratory $P$. aeruginosa strain PAO1 in mice immunized by footpad administration of the 3 vectors. AntiPAO1-specific IgG antibodies were detected in mice immunized with $1 \times 10^{9}$ particle units $(\mathrm{pu})$ of all 3 vectors at 28 days after administration (Figure 2). No significant titers of anti-P. aeruginosa were detectable in naive or AdZ-immunized animals. The titers were higher with AdZ.Epi8 than with AdZ.Epi6 or AdZ.Epi1 $(P<0.05$, both comparisons). Based on these data, all subsequent studies were carried out with the AdZ.Epi8 vector.

Western analysis of serum from mice immunized with AdZ.Epi8 showed bands corresponding to OprF with PAO1, the outer membrane fraction of PAO1, and recombinant OprF (Figure 3, lanes 4-6). In contrast, no signal was detectable in the serum of mice immunized with Ad expressing no transgene (AdNull) (Figure 3, lanes 1-3).

$M H C$ dependency of the humoral response. To evaluate whether the humoral immune response after immunization with AdZ. Epi8 was dependent on the MHC haplotype of the immunized mice, we administered AdZ.Epi8 subcutaneously to 3 strains of mice with different $\mathrm{MHC}$ haplotypes. Compared with those of $\mathrm{C} 57 \mathrm{BL} / 6$ and $\mathrm{BALB} / \mathrm{c}$ mice, the IgG anti-OprF titers were higher in CBA mice $(P<0.01$, both comparisons; Figure 4A), suggesting that Epi8 functions in a haplotype-dependent manner. The predominant IgG subclass response generated against Epi8 in $\mathrm{C} 57 \mathrm{BL} / 6$ mice was IgG2b; in BALB/c mice, it was IgG2b more than IgG2a; and in CBA mice, it was IgG2a more than IgG2b, which was more than IgG3 (Figure 4B). Epi8 not only is well characterized as a B cell epitope (21) but also represents a T helper epitope required for a strong humoral response against OprF, more prevalent in CBA mice with a $\mathrm{H}-2^{\mathrm{k}}$ haplotype than in C57BL/6 $\left(\mathrm{H}-2^{\mathrm{b}}\right)$ or BALB/c $\left(\mathrm{H}-2^{\mathrm{d}}\right)$ mice $(34,35)$.
Cellular response to AdZ.Epi8. To evaluate the recognition of Epi8 in the cellular immune response, we tested $\mathrm{T}$ cells of immunized C57BL/ 6 mice for their responsiveness to Epi8. CD4 and CD8 Epi8-specific IFN- $\gamma$ responses were detected in spleen cells of mice 10 days after immunization with AdZ.Epi8 (Figure 5). Mice immunized with AdZ.Epi8 demonstrated an increased frequency of Epi8-specific IFN- $\gamma$-positive CD4 (18\%) and CD8 (36\%) T cells, compared with AdZ-immunized or unimmunized mice $(10 \%$ CD4 and $13 \%$ CD8, and 5\% CD4 and 6\% CD8, respectively). The $\beta$-galactosidase-specific IFN- $\gamma$-positive CD 4 and CD8 cells were increased above the background of unpulsed DCs in the spleens of mice immunized with $\mathrm{AdZ}$ (24\% and 35\%, respectively) or AdZ. Epi8 (20\% and 32\%, respectively) but not those of unimmunized mice ( $5 \%$ and $3 \%$, respectively). Together, these observations are consistent with the conclusion that AdZ.Epi8 induced an Epi8-specific cellular response demonstrated by the presence of IFN- $\gamma$-secreting CD4 and CD8 T cells specific for the OprF

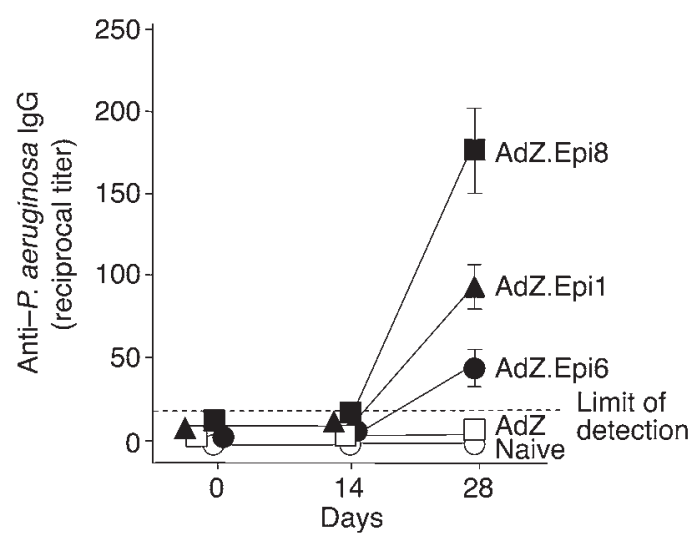

Figure 2

Humoral response to $P$. aeruginosa after immunization with Ad vectors with OprF epitopes in the hexon protein of the Ad capsid. C57BL/6 mice were either not immunized (Naive) or immunized via the subcutaneous route with AdZ.Epi1, AdZ.Epi6, AdZ.Epi8, or AdZ at a dose of $1 \times 10^{9}$ pu/animal. Total IgG antibodies against $P$. aeruginosa were determined by ELISA at 0, 2, and 4 weeks after administration, using the laboratory $P$. aeruginosa strain PAO1 as the antigen. Data are shown as a single measurement of pooled sera obtained from 5 individual mice per group. 


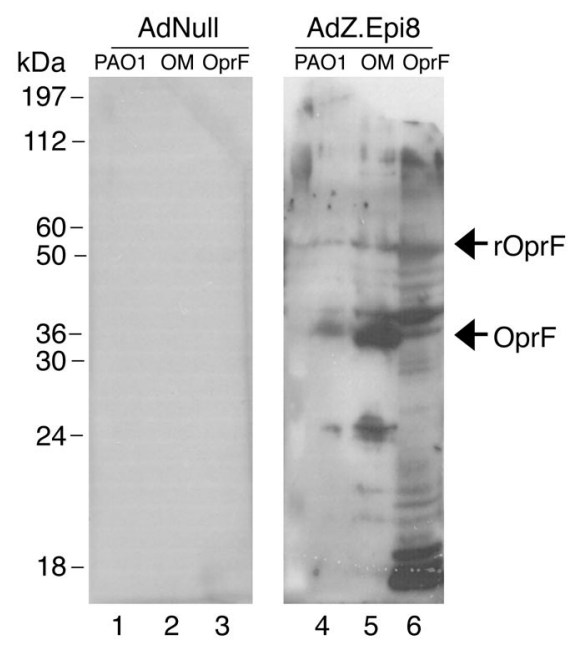

epitope. No significant Epi8-specific IL-4 staining was detected in CD4 T cells (not shown).

Protection against pulmonary infection with $P$. aeruginosa. To evaluate the protective effect of immunization with AdZ.Epi8 against pulmonary infection with $P$. aeruginosa, we challenged mice with a lethal dose $\left(5 \times 10^{5} \mathrm{CFUs}\right)$ of agar-encapsulated PAO1 5 weeks after subcutaneous immunization. This model usually results in death 2-4 days after challenge and has been used to evaluate the protective effects of immunization (36-38). The mice typically start to appear moribund 24-48 hours after infection. Bacteremia was detected at 48 hours after administration in 2 of 5 mice (not shown), indicating that part of the morbidity observed may be due to sepsis.

Unimmunized mice or mice infected with $\mathrm{AdZ}$ died within the first 3 days after challenge with PAO1 (Figure 6A). Histological analysis of the lungs after 48 hours showed bacteria with inflammation (Figure 6B). In contrast, $80 \%$ of the mice immunized with AdZ.Epi8 survived more than 2 weeks $(P<0.05)$. All the mice immunized with a high dose of heat-inactivated $\mathrm{PAO} 1$ survived, suggesting that protective immunity comparable to that of immunization with the whole organism can be elicited by immunization with the epitope-express-

\section{Figure 3}

Anti-P. aeruginosa and anti-OprF after immunization with AdZ.Epi8. Sera from C57BL/6 mice immunized subcutaneously with AdZ.Epi8 (lanes 4-6) or AdNull (lanes 1-3) at a dose of $1 \times 10^{10} \mathrm{pu} / \mathrm{mouse}$ were analyzed by Western blot for the presence of antibodies against whole PAO1 (lanes 1 and 4), the outer membrane of PAO1 (OM; lanes 2 and 5), or purified OprF (OprF; lanes 3 and 6). The bands representing OprF in the PAO1 preparation and recombinant OprF (rOprF) are shown.

ing Ad. Similar protective effects of immunization with AdZ.Epi8 were observed when mice were challenged with the clinical $P$. aeruginosa isolate MI6 $(P<0.05$ compared with AdZ; Figure 6C) or PA514 $(P<0.01$ compared with AdZ; Figure 6D). To ensure that OprF is conserved among clinical isolates of $P$. aeruginosa, we sequenced the OprF gene from 10 different clinical $P$. aeruginosa isolates derived from individuals with CF, including MI6 and PA514. The nucleotide and the derived protein sequence of OprF were identical among the strains and the Epi8 sequence was present in all isolates.

Boosting of the anti-OprF immune response. Repeated immunization with AdEpi8 resulted in boosting of the anti-OprF humoral and cellular response. Mice immunized twice with AdZ.Epi8 2 weeks apart had anti-OprF IgG titers present in the serum at 2 weeks after the second immunization 7 -fold higher than those of mice who had only received a single dose of AdEpi8, and anti-OprF titers 10-fold higher than those of mice immunized with a single dose of $\mathrm{AdZ}$. Epi8 followed by AdNull ( $P<0.05$, both comparisons; Figure 7A). No significant anti-OprF IgG was detected after 2 immunizations with AdNull or AdNull followed by AdZ.Epi8 $(P>0.1)$. In contrast, the anti- $\beta$-galactosidase IgG titers were comparable in all groups that had received immunization with AdZ.Epi8 first $(P>0.1$, all comparisons; Figure $7 \mathrm{~B})$. No anti- $\beta$-galactosidase IgG was detected after immunization with AdNull, whereas a small response (titer less than 100 compared with that of groups with immunization with AdZ.Epi8 first) was detected in the mice immunized with AdNull followed by a second immunization with AdZ. Epi8 2 weeks after the first $(P<0.05$ compared with mice immunized with AdZ.Epi8 first). To evaluate whether immunization with the Epi8 peptide alone or after immunization with AdZ.Epi8 would elicit anti-OprF humoral immune responses, we used Epi8 peptide at
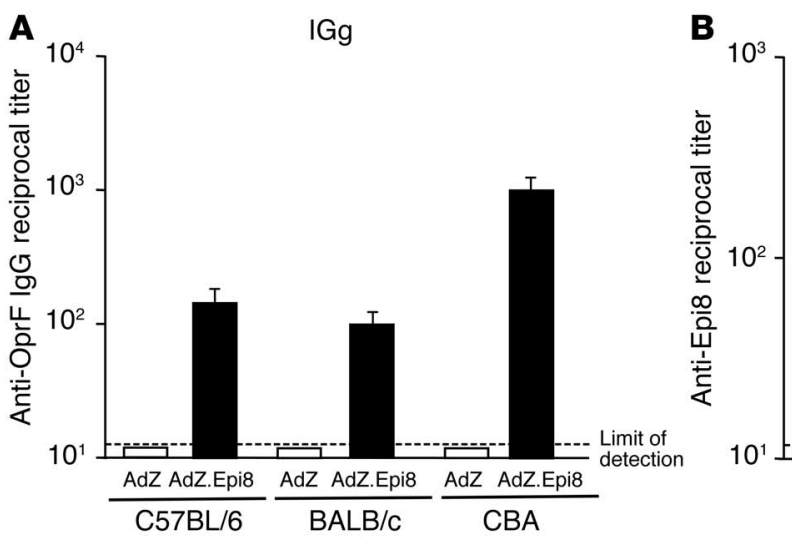

Figure 4

MHC haplotype influences the humoral response to OprF after immunization with AdZ.Epi8. (A and B) C57BL/6 (H2-Ab), BALB/c (H2-Ed), or CBA (H2-Ek) mice were immunized via the subcutaneous route with AdZ.Epi8 or AdZ at a dose of $1 \times 10^{10}$ pu/animal. (A) Total anti-OprF IgG titers determined at 2 weeks by ELISA. (B) IgG subclasses of antibodies against Epi8. Data are shown as single measurement of pooled sera obtained from 5 individual mice per group. The dashed lines indicate the limit of detection. 

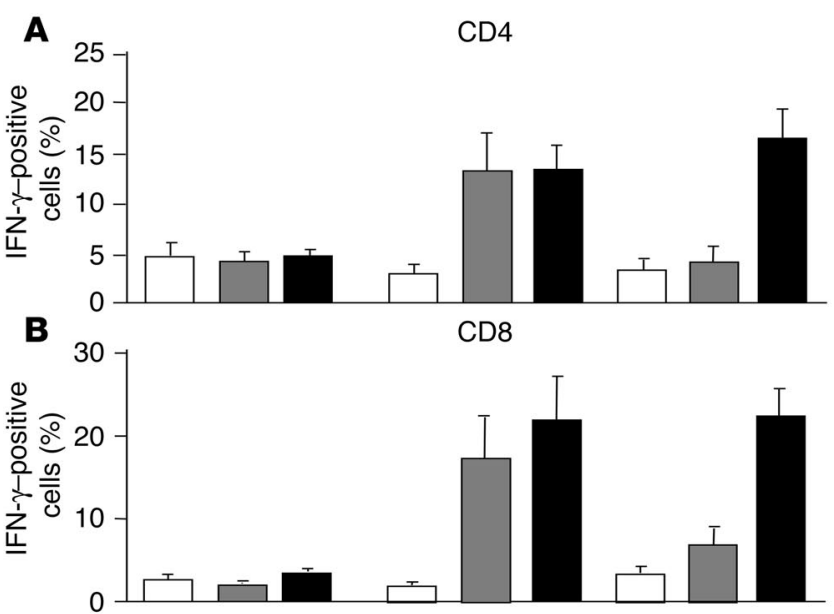

Immunization Control AdZ AdZ.Epi8 Control AdZ AdZ.Epi8 Control AdZ AdZ.Epi8 Stimulation $\mathrm{DC} \quad \frac{\mathrm{DC}+\beta-\mathrm{gal}}{\mathrm{DC}+\mathrm{Epi8}}$

a dose equimolar to the number of Epi8 epitopes administered with the $1 \times 10^{10}$-pu dose of AdZ.Epi8 (720 Epi8 per capsid = $12 \mathrm{pmol}$ ) and administered this subcutaneously to C57BL/6 mice, followed by a boost with Epi8 peptide or AdZ.Epi8 2 weeks later. Antibodies against OprF IgG were again detectable after single administration of AdZ.Epi8 and were boosted after a second administration of AdZ.Epi8 ( $P<0.05$; Figure 8$)$. However, immunization with Epi8 once or twice, either before or after immunization with AdZ.Epi8, did not induce significant anti-OprF IgG titers (Figure 8).

To evaluate the recognition of Epi8 in the cellular immune response after repeated administration with AdZ.Epi8, we tested $\mathrm{T}$ cells of immunized C57BL/ 6 mice for their responsiveness to Epi8. CD4 Epi8-specific IL-4 (Figure 9A) as well as CD4 (Figure 9B) and CD8 (Figure 9C) Epi8-specific IFN- $\gamma$ were significantly increased in spleen cells of mice 10 days after repeated immunization with AdZ.Epi8 compared with that after single administration of AdZ.Epi8 (32 versus 45 spots per $10^{5}$ cells for CD4 IL-4, 102 versus 202 spots per $10^{5}$ cells for CD4 IFN- $\gamma$ and 49 versus 118 spots

\section{Figure 6}

Ability of immunization with AdZ.Epi8 to protect against pulmonary challenge with $P$. aeruginosa. (A-D) C57BL/6 mice were immunized via the subcutaneous route with AdZ.Epi8 at a dose of $1 \times 10^{10} \mathrm{pu} /$ animal. Immunization with $\mathrm{AdZ}$ or heat-inactivated PAO1 $\left(1 \times 10^{8} \mathrm{CFU} /\right.$ mouse) served as the control. Five weeks after immunization, the mice were challenged with a lethal intratracheal dose of agar-encapsulated $P$. aeruginosa and survival was monitored for 2 weeks (A, C, and D) or lungs were assessed by histology (B). (A) Challenge with laboratory strain PAO1. (B) Lung morphology 48 hours after challenge with agar-encapsulated PAO1 compared with lung morphology of an uninfected mouse. Shown are hematoxylin and eosin-stained sections of formalin-fixed lungs. Scale bar: $0.5 \mu \mathrm{m}$. (C) Challenge with the clinical isolate MI6. (D) Challenge with the clinical isolate PA514.

\section{Figure 5}

CD4 and CD8 T cell IFN- $\gamma$ response after immunization with AdZ.Epi8. (A and B) C57BL/6 mice were immunized with AdZ.Epi8 or AdZ at a dose of $1 \times 10^{10} \mathrm{pu} /$ animal via the subcutaneous route. Ten days after immunization, CD4 and CD8 cells were isolated from spleens and the IFN- $\gamma$ response after in vitro stimulation with Epi8 or $\beta$-galactosidase was determined by intracellular cytokine staining. Shown are data for CD4 (A) and CD8 (B) cells after immunization with nothing (Control), $A d Z$, or AdZ.Epi8 and in vitro stimulation with DCs alone (DC), DCs plus $\beta$-galactosidase (DC + $\beta$-gal) or DCs plus Epi8 (DC + Epi8). Data represent the mean of pooled cells from 5 individual mice per group from 3 separate experiments.

per $10^{5}$ cells for CD8 IFN- $\gamma$; determined by enzyme-linked immunospot [ELISPOT] assay; $P<0.05$ for all comparisons; Figure 9). The $\beta$-galactosidase-specific IL-4 CD 4 and IFN- $\gamma$ CD 4 and CD 8 responses were not increased after repeated administration compared with single administration.

These data are consistent with the concept that immunization with Ad of the same serotype induces anti-Ad immune responses that prevent productive infection and expression of the transgene with subsequent administrations. Because expression of an epitope as part of the Ad capsid does not require gene expression, repeated administration results in an increased immune response against the epitope and overcomes the MHC class II haplotype restriction after single administration. Furthermore, the data demonstrate that the adjuvant effect of Ad surpasses the effect of using an equimolar amount of the Epi8 peptide and a common adjuvant such as complete Freund's adjuvant.

\section{Discussion}

The present study describes a novel strategy for using capsidmodified Ad vector expressing immunogenic peptides of $P$. aeruginosa OprF to immunize against lung infections with $P$. aeruginosa.
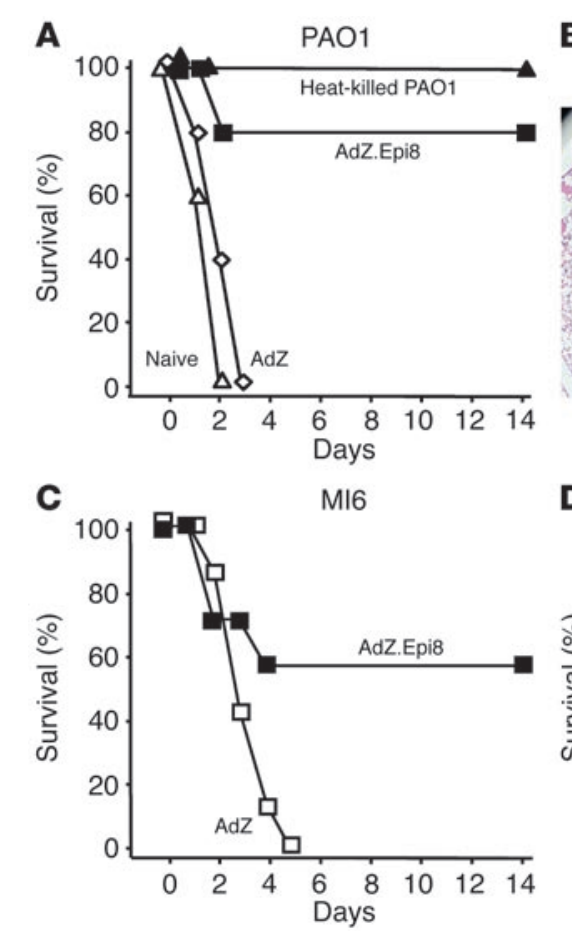

\section{B PAO1 histology}
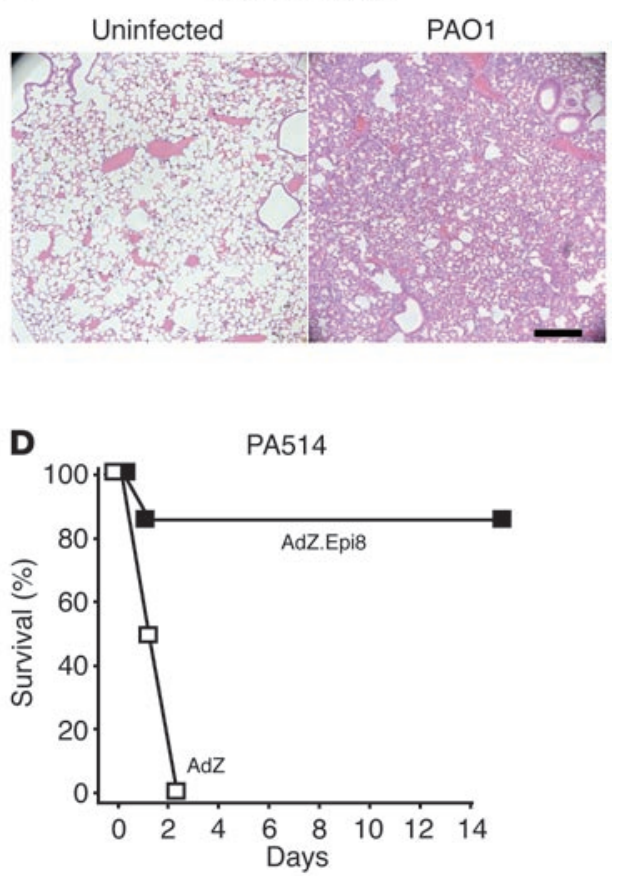

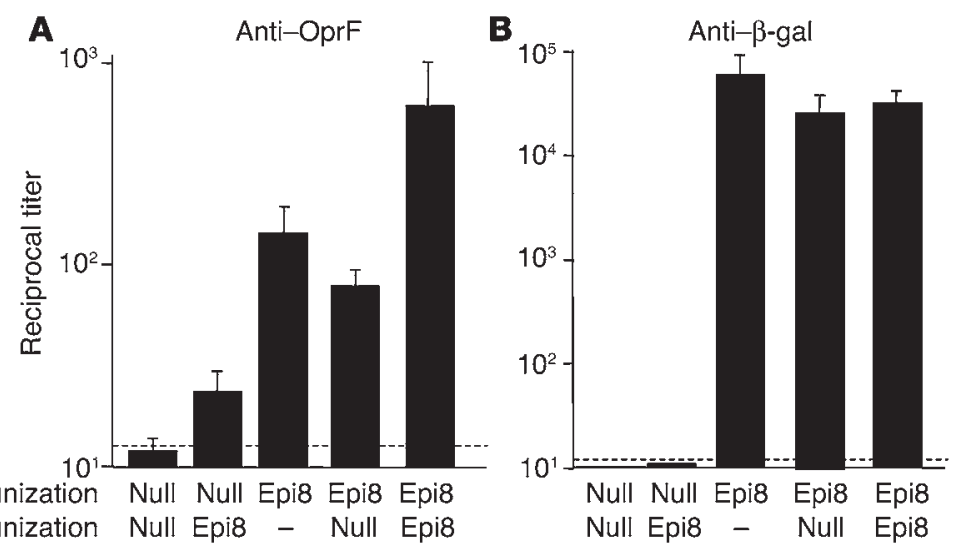

\section{Figure 7}

Repeated administration of AdZ.Epi8 results in boosting of the anti-OprF immune response. (A and B) C57BL/6 mice were immunized via the subcutaneous route with AdZ.Epi8 (Epi8), AdNull (Null) or nothing (-) at a dose of $1 \times 10^{10} \mathrm{pu} /$ animal followed by a second immunization 2 weeks later. Total IgG antibodies against OprF (Anti-OprF; A) or $\beta$-galactosidase (Anti$\beta$-gal; B) were assessed by ELISA at 4 weeks after the first immunization. Data are shown as mean \pm SEM of 5 mice per group of 1 representative of 3 independent experiments.

Immunization with Ad expressing a predominant B cell epitope of OprF in the Ad hexon resulted in anti-P. aeruginosa and anti-OprF humoral as well as peptide-specific cellular responses. Immunization with AdZ.Epi8 induced sufficient immunity to protect against a lethal intrapulmonary challenge with 3 different strains of $P$. aeruginosa (1 laboratory strain and 2 clinical isolates derived from CF patients). Most importantly, this strategy enabled repeated administration of the same vector with resultant boosting of the anti-P. aeruginosa immune response.

OprF peptides as a vaccine against $P$. aeruginosa. $P$. aeruginosa is a common respiratory pathogen present in the respiratory tracts of patients with CF, bronchiectasis, and immunodeficiency. The host response to $P$. aeruginosa is a complex immune and inflammatory reaction that results in damage to the respiratory tract $(1,2)$. Antibodies as well as cell-mediated immunity seem to be associated with protective immunity, but an efficient vaccine against pulmonary colonization with $P$. aeruginosa is not yet available (39-46). Various components of $P$. aeruginosa have been tested as vaccine candidates in animal studies and humans, among them the outer membrane protein OprF. OprF is a major outer membrane protein with porin activity $(47,48)$ that is surface exposed and is antigenically conserved in wild-type strains of $P$. aeruginosa $(49,50)$. Antibodies against $\mathrm{OprF}$ are associated with protection in animal models and human infection and are present in the serum of individuals with CF chronically colonized with $P$. aeruginosa in the lung $(22-28,51,52)$. Immunization with recombinant OprF has been shown to generate protective immune responses, and recombinant OprF is being tested as a vaccine candidate against infections with $P$. aeruginosa in animals and humans (22-28). Genetic immunization with DNA encoding an OprF/OprI hybrid via a gene gun in mice resulted in humoral immunity against P. aeruginosa (29). Various immunogenic peptides have been identified in the outer loops of OprF, among them the B cell epitopes TDAYNQKLSERRAN (peptide 9, identical to Epi6) and NATAEGRAINRRVE (peptide 10, identical to Epi8) (21). Immunization with a modified cowpea mosaic virus expressing peptide 9 or 10 induced IgG-binding antibodies against OprF and opsonizing antibodies against $P$. aeruginosa in mice (22). Similar results were reported with the use of OprF peptides expressed by recombinant influenza virus (53).

Ad as a base for a genetic vaccine. Ad vectors have been successfully used as vaccines against a variety of microorganisms and tumors (54-57). Ad immunization strategies are usually based on the efficient infection of a variety of cells by Ad in vivo, resulting in expression of an antigen encoded by the Ad expression cassette, and on Ad functioning as an adjuvant $(5,7,12,16)$. Relevant for the use of Ad vectors as a vaccine is their ability to infect DCs, as the interaction of Ad with DCs is critical for the induction of a strong antiAd and anti-transgene immune response (3-6, 8-11). Depending on the microorganisms or tumor targeted by the vaccination, the generation of humoral and/or cellular responses are the major goal. The generation of protective immunity against extracellular bacteria such as $P$. aeruginosa requires the generation of humoral immunity against the organism by the vaccine. One attractive feature of the use of Ad for genetic vaccination is the possibility of modifying the Ad capsid to enhance immune responses or change the Ad tropism. Targeting Ad to antigen-presenting cells by adding the integrinbinding motif RGD to the fiber knob enhances anti-transgene cellular immune responses after a single dose in mice $(10,58)$. However, anti-Ad immune responses impair the efficacy of Ad vectors of the same serotype, as pre-existing neutralizing antibodies against Ad prevent the cellular uptake of Ad and expression of the transgene in a previously immunized host $(5,12,14-16)$. In contrast, anti-Ad immunity can be boosted by repeated infection with wild-type Ad or Ad vectors, leading to an increase in anti-Ad humoral responses with subsequent infections $(11,12,16)$. With the incorporation of peptides into the Ad hexon, the peptide-specific immune response should be boosted similar to the boosting seen

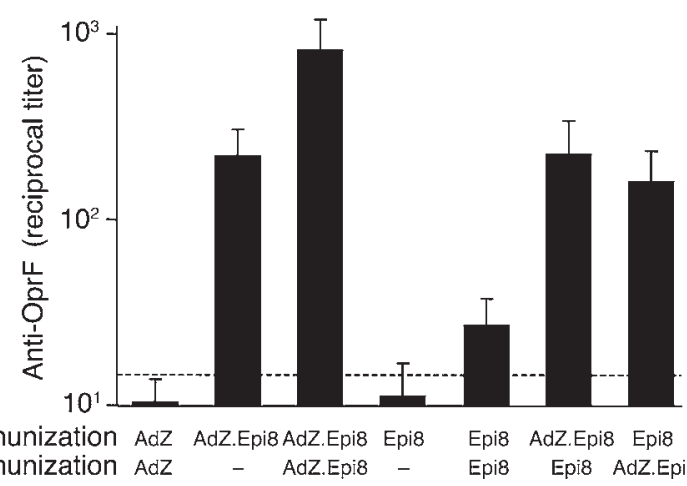

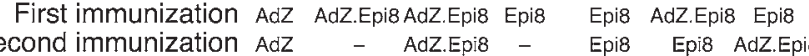

\section{Figure 8}

Anti-OprF humoral response after administration of Epi8 peptide compared with AdZ.Epi8. C57BL/6 mice were immunized via the subcutaneous route with AdZ.Epi8 or $\mathrm{AdZ}\left(1 \times 10^{10} \mathrm{pu} / \mathrm{animal}\right)$ or with an equimolar amount of Epi8 peptide $(12 \mathrm{pmol}=3.6 \mathrm{ng} / \mathrm{mouse})$ in complete Freund's adjuvant, followed by a second immunization 2 weeks later. Total IgG antibodies against OprF were assessed by ELISA at 4 weeks after the first immunization. Data are shown as mean \pm SEM of 4 mice per group. 
A
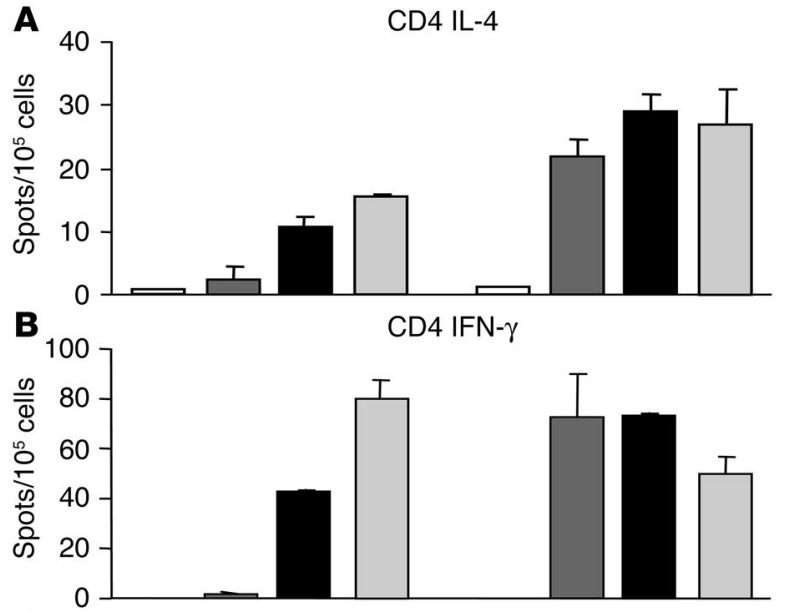

C

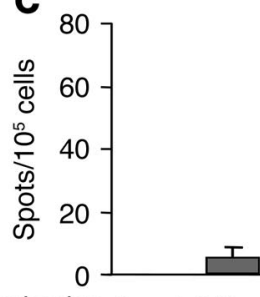

Immunization Control AdZ AdZ.Epi8 AdZ.Epi8

Stimulation

$\times 2 \quad \times 1$ $\times 2$

CD8 IFN- $\gamma$

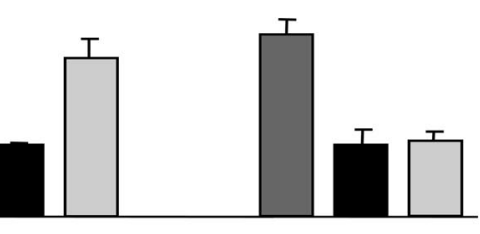

Control AdZ AdZ.Epi8 AdZ.Epi8

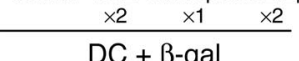

$D C+\beta-g a l$

with the anti-Ad responses. Of the Ad outer capsid proteins, hexon is the most abundant and is the protein against which the majority of the anti-Ad immune responses are generated. An 8-amino acid sequence from the major antigenic site in the VP1 capsid protein of poliovirus type 3 engineered into loop 1 of the Ad hexon protein elicited neutralizing antibodies against poliovirus in rabbits (19). Heterologous peptides have been inserted into hypervariable region 5 of the hexon without loss of infectivity $(59,60)$.

Immunization with the AdEpi8 vector induces immunity. Immunization with the Ad.Epi vectors in the present study induced humoral and cellular responses. The serum IgG response was detected using either the whole $P$. aeruginosa organism or $\mathrm{OprF}$ as an antigen. Although the humoral response in the $\mathrm{C} 57 \mathrm{BL} / 6$ strain was less than that of CBA mice, Epi8-specific CD4 and CD8 responses were induced. The CD4 IFN- $\gamma$ response was about twice as high as the CD4 IL-4 response, as measured by ELISPOT assay. This pattern stayed consistent after repeated immunization with AdZ.Epi8, indicating Epi8 is an powerful epitope for the Th1 response in C57BL/ 6 mice. The low amount of IL-4 secretion in the intracellular staining and ELISPOT analysis was also reflected in the low antibody titer against Epi8 in this mouse strain. The role of $\mathrm{T}$ cell-mediated immunity has received less attention than the humoral immunity in the development of a vaccine against $P$. aeruginosa but is part of the response against natural infection with the organism. Normal human T cells proliferate in response to $P$. aeruginosa (39), and intestinal immunization of rats with $P$. aeruginosa results in protective $\mathrm{T}$ cell-dependent immunity (41). Protective T cell responses have been described in mice after low systemic doses of live $P$. aeruginosa, and protection against $P$. aeruginosa is transferred by CD4 and CD8 T cells $(41,43)$. The induction of protective immunity against pulmonary challenge with $P$. aeruginosa after immunization with $P$. aeruginosa-pulsed DCs

\section{Figure 9}

Repeated administration of AdZ.Epi8 results in boosting of the Epi8specific cellular immune response. (A and B) C57BL/6 mice were immunized via the subcutaneous route with AdZ.Epi8 or AdZ at a dose of $1 \times 10^{10} \mathrm{pu} / \mathrm{animal}$. Some mice were not immunized further $(\times 1)$; others received a second immunization 2 weeks later $(\times 2)$. Ten days after the second immunization, CD4 and CD8 cells were isolated from spleens and the IL-4 and IFN- $\gamma$ responses after in vitro stimulation with Epi8 or $\beta$-galactosidase were assessed by ELISPOT assay. Shown are data for CD4 IL-4 (A), CD4 IFN- $\gamma$ (B), and CD8 IFN- $\gamma(\mathbf{C})$ after in vitro stimulation with DCs plus $\beta$-galactosidase or DCs plus Epi8. For each condition, data were normalized to the total number of polyclonal cells stimulated with PMA/ionomycin.

has been shown to be dependant on the presence of CD4 T cells (38). Although both humoral and cellular responses were induced after immunization in the present study, it is not clear what their individual contribution to the protection against the lethal challenge model is, a model frequently used to evaluate protective immunity against $P$. aeruginosa (61).

MHC dependence of the humoral response. Ad-based vaccines usually express the antigen in the Ad expression cassette, resulting in a $\mathrm{T}$ helper cell-dependent humoral and cellular response against the transgene (54-57). Furthermore, the generation of peptide-specific antibodies is influenced by several factors, including the MHC-type genotype, the avidity of the peptide for the MHC, and the strength of interaction formed with the $\mathrm{T}$ cell receptor, with high affinity favoring predominantly cellular responses and low affinity favoring humoral responses (62). The humoral response to AdZ.Epi8 was dependent on the MHC background of the immunized mice. Our epitope analysis of Epi8 using the 2 databases Rankpep and SYFPEITHI revealed a strong binding activity to $\mathrm{H}-2 \mathrm{E}^{\mathrm{k}}$, suggesting that antibody production may be based on the repertoire of MHC class II haplotypes in different mice strains $(63,64)$. The higher titer in CBA mice $\left(\mathrm{H}-2 \mathrm{E}^{\mathrm{k}}\right)$ confirmed this prediction, in spite of the effect of Ad's functioning as a global adjuvants, indicating genetic restriction in the $\mathrm{B}$ cell response to peptides incorporated in viral envelopes $(34,65)$. The predominance of the Th1 type IgG subclass IgG2a as the dominant response in C57BL/6 mice may be a reflection of the adjuvant effect of the Ad vector. The development of high-affinity antibodies is strongly related to early B cell activation events (66). Continuous B cell stimulation by the antigen and maturation of high-affinity antibodies depend on the presence of $T$ helper cells via the presentation of related peptides to the $B$ cells (14). As we have shown in our model with Epi8, the absence of such a helper effect results in the development of low-titer antibodies in the serum of mice with less optimal MHC haplotype (C57BL/6 and $\mathrm{BALB} / \mathrm{c}$ ), suggesting that the $\mathrm{T}$ helper epitope is required for high antigen-specific IgG production. Furthermore, the presence of a strong IFN- $\gamma$-mediated Th1 response in the absence of a strong Th2 type component (IL-4) appears to suppress high-titer Epi8-specific antibody production. To further optimize this model for immunizations of humans, OprF peptides must be further identified that are recognized in a more genetically unrestricted manner.

Boost of bumoral and cellular responses. Anti-Ad immunity after administration of Ad vectors generally does not allow subsequent productive infection with an Ad vector based on the same serotype (5, 12, 14-16). Usually thought to be a hurdle for the use of Ad as a gene therapy tool, repeated administration of the same vector would be helpful in the development of Ad-based vaccines to enable boosting 
of antigen-specific immune responses. In our study, repeated immunization with AdZ.Epi8 resulted in boosting of the anti-epitope and not the anti-transgene IgG and cellular response. The potent adjuvant effect of using an Ad vector with the OprF peptides incorporated into the capsid was demonstrated by the lack of a significant humoral response after immunization with an equimolar amount of the Epi8 peptide alone with complete Freund's adjuvant. Administration of a control AdNull vector followed by immunization with AdZ. Epi8 resulted in a decreased but detectable response against OprF with no detectable response against the transgene, suggesting that the vector is removed to some extent before recognition by antigenpresenting cells. The strategy of incorporating epitopes into the Ad capsid, perhaps combined with expression of cDNA encoding the same antigen in the expression cassette, will also be valuable in the development of Ad-based vaccines against other pathogens.

\section{Methods}

Adenovirus vectors. The recombinant Ad vectors used in this study are E1a, partial E1b, and partial E3 vectors based on the Ad5 genome. The expression cassettes were inserted into the $\mathrm{E} 1$ region and contained the human cytomegalovirus intermediate early enhancer/promoter, the transgene, and a simian virus 40 poly(A)/stop signal. The vectors expressed either $\beta$-galactosidase, referred to as " $Z$ " in the vector (AdZ), or no transgene (AdNull) (67). The OprF epitope Epi1 (QYGLEKRDNGHQGE), Epi6 (TDAYNQKLSERRAN), or Epi8 (NATAEGRAINRRVE) was inserted into loop 1 of the hypervariable region 5, residues 268-269, of the Ad5 hexon gene (Figure 1). The vectors were used with equal physical particle concentrations $(\mathrm{pu})$ and were propagated and purified as described previously (68-70).

Bacteria. The $P$. aeruginosa strains used in this study were the laboratory strain PAO1 and the clinical strains MI6 (provided by J. Burns, University of Washington, Seattle, Washington, USA) and PA514 (provided by A. Prince, Columbia University, New York, New York, USA) $(37,71)$. Bacteria were grown from frozen stocks in tryptic soy broth (Difco) at $37^{\circ} \mathrm{C}$ to mid-log phase, were washed 3 times with PBS, pH 7.4, and were resuspended in PBS at the desired concentration as determined by spectrophotometry. Numbers of bacteria were confirmed by determination of the CFU of diluted aliquots on MacConkey agar plates (Difco). Bacteria were heat-inactivated at $56^{\circ} \mathrm{C}$ for 1 hour. P. aeruginosa-containing agar beads were prepared based on the method of Starke et al. (72) and were used in a lethal respiratory infection with $P$. aeruginosa as described previously $(37,38)$. Briefly, a logphase culture of $P$. aeruginosa suspended in warm tryptic soy agar $\left(52^{\circ} \mathrm{C}\right)$ was added to mineral oil with vigorous stirring and the mixture was cooled on ice. The $P$. aeruginosa-impregnated beads were washed extensively with PBS, and the density of viable bacteria enmeshed in agar beads was determined by plating of serial dilutions of homogenized beads.

Mice. Female C57BL/6 $\left(\mathrm{H}-2^{\mathrm{b}}\right), \mathrm{BALB} / \mathrm{c}\left(\mathrm{H}-2^{\mathrm{d}}\right)$, or CBA $\left(\mathrm{H}-2^{\mathrm{k}}\right)$ mice were obtained from Taconic Farms. The animals were housed under specific pathogen-free conditions and were used at 6-8 weeks of age. The mice were immunized by subcutaneous footpad injection of $30 \mu \mathrm{l}$ of Ad diluted in PBS or of Epi8 peptide (AnaSpec) in complete Freund's adjuvant (Sigma-Aldrich).

Preparation of $P$. aeruginosa outer membrane fraction. Outer membranes of $P$. aeruginosa PAO1 were prepared by the method of Shand et al. (73). PAO1 grown to stationary phase at $37^{\circ} \mathrm{C}$ overnight were harvested by centrifugation. The pellet was resuspended in water and was broken by sonication. Unbroken cells were removed by centrifugation at $5,000 \mathrm{~g}$ for 10 minutes. $N$-laurylsarcosine, sodium salt (Sigma-Aldrich), was added to the supernatant to a concentration of $2 \%$ and then samples were incubated at $20^{\circ} \mathrm{C}$ for 30 minutes. The broken cells were then ultracentrifuged $38,000 \mathrm{~g}$ for 1 hour, resuspended in PBS.

Expression of OprF. The recombinant vector Smt3-OprF with an N-terminal histidine tag was constructed by cloning of the PCR-amplified OprF gene (forward primer, 5'-CCCGGATCCAGAATGCAGGGCCAGAAC-3'; reverse primer, $5^{\prime}$-CCCAAGCTTTTTACTTGGCCTCAGCCTCC-3') into the expression vector $\mathrm{Sm} 3$ (Invitrogen Corp.). The recombinant vector Smt3His-OPRF was transformed into Escherichia coli strain BL21. The recombinant fusion protein was purified by nickel-chelating affinity chromatography from a single transformant. Briefly, the cultures were grown to an $\mathrm{OD}_{600}$ of 0.8 , were stimulated with $0.5 \mathrm{mM}$ isopropyl $\beta$-D-thiogalactopyranoside for 3 hours at $27^{\circ} \mathrm{C}$ and were collected by centrifugation $(3000 \mathrm{~g})$. The cell pellet was washed and resuspended in TBS buffer I ( $50 \mathrm{mM}$ Tris, $0.5 \mathrm{mM}$ EDTA, and $50 \mathrm{mM} \mathrm{NaCl}, \mathrm{pH}$ 7.4). Cell lysis was induced by sonication 3 times (each a 10 -second pulse with a 1-minute interval) and the lysate was cleared by centrifugation $\left(18,000 \mathrm{~g}\right.$ at $\left.4^{\circ} \mathrm{C}\right)$. Imidazol $(10 \mathrm{mM})$ was added and the crude extract was placed on nickel-bound resin agarose (Prebound; QIAGEN) equilibrated with the TBS buffer I described above. Unbound material was washed out successively with 10 column volumes of TBS buffer I. The specific protein was eluted in with 5 column volumes of TBS buffer II (50 mM Tris, $0.5 \mathrm{mM}$ EDTA, $50 \mathrm{mM} \mathrm{NaCl}$, and $300 \mathrm{mM}$ imidazol, $\mathrm{pH}$ 7.4) and dialyzed extensively against PBS. The recombinant vector Smt3-Epi8 was constructed and purified accordingly.

Anti-P. aeruginosa bumoral responses. For evaluation of the humoral response against $P$. aeruginosa after immunization with the 3 AdZ.Epi vectors, $\mathrm{C} 57 \mathrm{BL} / 6, \mathrm{BALB} / \mathrm{c}$, or CBA mice were immunized subcutaneously with AdZ.Epi1, AdZ.Epi6, or AdZ.Epi8 at a dose of $1 \times 10^{9}$ or $1 \times 10^{10} \mathrm{pu} / \mathrm{mouse}$. Mice injected with AdZ or AdNull at an equal dose or naive mice (PBS injected) served as controls. Serum was collected from the tail vein 14 and 28 days after immunization. Total IgM and IgG antibodies specific for P. aeruginosa or OprF were determined by ELISA. Microtiter plates (Nunc) were coated at $4^{\circ} \mathrm{C}$ for 12 hours with $1 \mu \mathrm{g} /$ well of heat-inactivated laboratory $P$. aeruginosa strain $\mathrm{PAO} 1$ or $\mathrm{OprF}$ in PBS. The plates were washed 3 times with PBS and were blocked for 30 minutes with $1 \%$ BSA (Sigma-Aldrich) in PBS. After 3 washes with $0.05 \%$ Tween 20 in PBS (TBST), sera were added in sequential 2-fold dilutions starting at 1:20 and plates were incubated for 1 hour. After 3 washes with TBST, goat anti-mouse IgG (Caltag Laboratories) was added at a concentration of $0.5 \mu \mathrm{g} / \mathrm{ml}$ and plates were incubated for an additional 1 hour. After 5 washes with TBST, swine anti-goat IgG (Caltag) was added at a concentration of $0.2 \mu \mathrm{g} / \mathrm{ml}$ for 1 hour and detection was accomplished using the Peroxidase Substrate Kit (Bio-Rad Laboratories). Absorbance at $415 \mathrm{~nm}$ was measured after 15 minutes. Titers were calculated as reciprocal dilutions 2 -fold above background values (substrate only). For titer determination, the absorbance values of all dilutions were extrapolated to the 2 -fold background value using a linear-fit function. The IgG subclass antibodies IgG1, IgG2a, IgG2b, and IgG3 against Epi8 were assessed on histidine-tagged Epi8-coated plates $(1 \mu \mathrm{g} /$ well) using goat IgG subclass antibodies against mouse (Bio-Rad Laboratories).

Epi8-specific cellular responses. After initial studies showed that the best humoral responses were with AdZ.Epi8, all subsequent studies were carried out with this vector. For assessment of the Epi8-specific cellular immune response, C57BL/ 6 mice were immunized subcutaneously with $1 \times 10^{10}$ pu of AdZ.Epi8 or AdZ; unimmunized mice served as controls. The frequency of antigen-specific T lymphocytes was determined by IFN- $\gamma-$ specific intracellular cytokine staining 10 days after Ad administration. $\mathrm{T}$ cells and DCs were isolated from spleen by passing of the spleen through nylon gauze $(100 \mu \mathrm{m})$. Subsequently, CD4 or CD8 T cells were purified by negative depletion using SpinSep T cell subset purification kits (StemCell Technologies). The purity of CD 4 and CD8 $\mathrm{T}$ cells was generally more than $95 \%$. Splenic DCs were purified from naive animals to serve as antigenpresenting cells by positive selection using CD11c MACS beads (Miltenyi Biotec) and double purification over 2 consecutive MACS LS+ columns (Miltenyi Biotec). The purity of DCs was more than $90 \%$. DCs $\left(5 \times 10^{6} / \mathrm{ml}\right)$ were pulsed for 3 hours with Epi8 peptide $(100 \mu \mathrm{M})$ or were incubated with 
$\beta$-galactosidase (100 $\mu \mathrm{g} / \mathrm{ml}$; Roche Molecular Biochemicals) in full RPMI medium supplemented with $10 \mathrm{mM}$ HEPES, pH 7.5 (BioSource International) and $50 \mu \mathrm{M} \beta$-mercaptoethanol (Sigma-Aldrich). CD4 $\left(2 \times 10^{5}\right)$ or CD8 $\left(1 \times 10^{5}\right) \mathrm{T}$ cells were incubated with splenic DCs, either pulsed with $\beta$-galactosidase or Epi8 or left untreated, at a ratio of 6:1 in flat-bottomed 96-well plates (Nunc). Cell counts were performed using a FACSCalibur flow cytometer (BD Biosciences) running at a constant flow rate, calibrated using QuantiBRITE Beads (BD Biosciences). After incubation for 48 hours, cells from triplicate wells were combined, washed, resuspended in PBS and 2\% FCS, and incubated for 30 minutes on ice with FITC-conjugated monoclonal antibodies against CD4 and CD8 (BD Biosciences) for the identification of CD4 and CD8 T cells, respectively. The cells were then fixed and permeabilized for 20 minutes at $4{ }^{\circ} \mathrm{C}$ with Cytofix/ Cytoperm reagent (BD Biosciences) and were washed twice in Perm/Wash solution (BD Biosciences). The cells were then stained $\left(30\right.$ minutes at $\left.4^{\circ} \mathrm{C}\right)$ for intracellular cytokines using PE-conjugated monoclonal antibodies against murine cytokine IFN- $\gamma$. PE-conjugated isotype controls were used in parallel. After 2 washes, the cells were suspended in PBS with 0.1\% BSA (Sigma-Aldrich) and were analyzed by flow cytometry.

For evaluation of the cellular response after repeated administration of AdZ.Epi8, the frequency of Epi8- and $\beta$-galactosidase-specific CD4 and CD8 $\mathrm{T}$ lymphocytes was determined with an IFN- $\gamma$ - and IL-4-specific ELISPOT assay 10 days after the second immunization. MAIPS- 45 plates (Millipore) were coated overnight at $4{ }^{\circ} \mathrm{C}$ with $5 \mu \mathrm{g} / \mathrm{ml}$ of the cytokine-specific capture antibodies AN18 (IFN- $\gamma$ ) or 11B11 (IL-4; Mabtech). CD4 and CD8 T cells from the spleen were purified by negative depletion using SpinSep $T$ cell subset purification kits (StemCell Technologies). The purity of the $\mathrm{T}$ cell subsets was generally more than $95 \%$. Splenic DCs were purified from naive animals to serve as antigen-presenting cells by positive selection using CD11c MACS beads (Miltenyi Biotec) and double-purification over 2 consecutive MACS LS+ columns (Miltenyi Biotec); the purity was more than $90 \%$. Prior to the addition of responder T cells and DCs, plates were blocked for 3 hours with full RPMI medium, supplemented with $10 \mathrm{mM}$ HEPES, pH 7.4 (BioSource International), and $50 \mu \mathrm{M} \beta$-mercaptoethanol (Sigma-Aldrich). T cells $\left(1 \times 10^{5}\right)$ were incubated with splenic DCs at a ratio of $6: 1$ with or without $\beta$-galactosidase or Epi8 peptide and were incubated for 20 hours (IFN) or 48 hours (IL-4). After plates were washed, $1 \mu \mathrm{g} / \mathrm{ml}$ biotinylated anti-IFN or anti-IL-4 (both from Mabtech) detection antibodies were added and the plates were incubated for 2 hours at $37^{\circ} \mathrm{C}$. Plates were then washed and the streptavidin-alkaline phosphatase conjugate (Vectastain $\mathrm{ABC}$ peroxidase kit; Vector Laboratories) was added. For final spot detection, 3-amino-9-ethylcarbazole substrate (Sigma-Aldrich) was added for 4 minutes and plates were rinsed with $\mathrm{H}_{2} \mathrm{O}$. The spots were counted by computer-assisted ELISPOT image analysis (Zellnet Consulting).
Protection against pulmonary challenge with P. aeruginosa. For determining if immunization with AdZ.Epi8 resulted in protective immunity against a lethal pulmonary challenge with $P$. aeruginosa, C57BL/ 6 mice were immunized subcutaneously with AdZ.Epi8 at a dose of $1 \times 10^{10} \mathrm{pu} / \mathrm{mouse}$. Mice injected with $\mathrm{AdZ}$ at equal doses or naive mice served as negative controls; mice immunized subcutaneously with $1 \times 10^{8} \mathrm{CFU}$ of heat-killed PAO1 served as positive controls. Five weeks after immunization, the mice were challenged with $P$. aeruginosa encapsulated in agar beads. Fifty microliters of the laboratory strain PAO1 $\left(5 \times 10^{5} \mathrm{CFU}\right)$ or the clinical strains MI6 $\left(1 \times 10^{8} \mathrm{CFU}\right)$ or PA514 $\left(5 \times 10^{7} \mathrm{CFU}\right)$ enmeshed in agar beads was inoculated intratracheally into the lungs of mice placed in a supine position. All mice were monitored daily for 14 days after infection. Animals that appeared moribund were sacrificed, and this was recorded as the date of death.

Statistical analysis. The data are presented as mean \pm SEM. Statistical analysis was performed using the nonpaired 2-tailed Student's $t$ test assuming equal variance. Statistical significance was determined at $P$ values of less than 0.05 . Survival estimates and median survivals were determined using the method of Kaplan and Meier.

\section{Acknowledgments}

We thank N. Mohamed and T. Virgin-Bryan for help in preparing this manuscript, and L. Lande for providing the histological analysis. These studies were supported in part by NIH grant U01 HL66952 and The Will Rogers Memorial Fund. S. Worgall was supported in part by The Parker B. Francis Foundation and the Cystic Fibrosis Foundation.

Received for publication August 23, 2004, and accepted in revised form February 8, 2005.

Address correspondence to: Ronald G. Crystal, Department of Genetic Medicine, Weill Medical College of Cornell University, 515 East 71st Street, S-1000, New York, New York 10021, USA. Phone: (212) 746-2258; Fax: (212) 746-8383; E-mail: geneticmedicine@med.cornell.edu.

Peter W. Roelvink's present address is: Benitec Inc., Mountain View, California, USA.

Thomas J. Wickham's present address is: EMD Lexigen, Billerica, Massachusetts, USA.

Imre Kovesdi's present address is: KILA Consultants LLC, Rockville, Maryland, USA.
1. Garau, J., and Gomez, L. 2003. Pseudomonas aeruginosa pneumonia. Curr. Opin. Infect. Dis. 16:135-143.

2. Gibson, R.L., Burns, J.L., and Ramsey, B.W. 2003. Pathophysiology and management of pulmonary infections in cystic fibrosis. Am. J. Respir. Crit. Care Med. 168:918-951.

3. Dietz, A.B., and Vuk-Pavlovic, S. 1998. High efficiency adenovirus-mediated gene transfer to human dendritic cells. Blood. 91:392-398.

4. Herrera, O.B., Brett, S., and Lechler, R.I. 2002. Infection of mouse bone marrow-derived dendritic cells with recombinant adenovirus vectors leads to presentation of encoded antigen by both MHC class I and class II molecules-potential benefits in vaccine design. Vaccine. 21:231-242.

5. Jooss, K., Yang, Y., Fisher, K.J., and Wilson, J.M. 1998. Transduction of dendritic cells by DNA viral vectors directs the immune response to transgene products in muscle fibers. J. Virol. 72:4212-4223.

6. Labow, D., Lee, S., Ginsberg, R.J., Crystal, R.G., and
Korst, R.J. 2000. Adenovirus vector-mediated gene transfer to regional lymph nodes. Hum. Gene Ther. 11:759-769.

7. Molinier-Frenkel, V., et al. 2002. Adenovirus hexon protein is a potent adjuvant for activation of a cellular immune response. J. Virol. 76:127-135.

8. Shiver, J.W., et al. 2002. Replication-incompetent adenoviral vaccine vector elicits effective anti-immunodeficiency-virus immunity. Nature. 415:331-335.

9. Sullivan, N.J., Sanchez, A., Rollin, P.E., Yang, Z.Y., and Nabel, G.J. 2000. Development of a preventive vaccine for Ebola virus infection in primates. Nature. 408:605-609.

10. Worgall, S., et al. 2004. Modification to the capsid of the adenovirus vector that enhances dendritic cell infection and transgene-specific cellular immune responses. J. Virol. 78:2572-2580.

11. Zhang, Y., et al. 2001. Acute cytokine response to systemic adenoviral vectors in mice is mediated by dendritic cells and macrophages. Mol. Ther. 3:697-707.

12. Hackett, N.R., et al. 2000. Antivector and antitransgene host responses in gene therapy. Curr. Opin. Mol. Ther. 2:376-382.

13. Harvey, B.G., et al. 1999. Airway epithelial CFTR mRNA expression in cystic fibrosis patients after repetitive administration of a recombinant adenovirus. J. Clin. Invest. 104:1245-1255.

14. Mack, C.A., et al. 1997. Circumvention of antiadenovirus neutralizing immunity by administration of an adenoviral vector of an alternate serotype. Hum. Gene Ther. 8:99-109.

15. Mastrangeli, A., et al. 1996. "Sero-switch" adenovirus-mediated in vivo gene transfer: circumvention of anti-adenovirus humoral immune defenses against repeat adenovirus vector administration by changing the adenovirus serotype. Hum. Gene Ther. 7:79-87.

16. Yang, Y., Li, Q., Ertl, H.C., and Wilson, J.M. 1995. 
Cellular and humoral immune responses to viral antigens create barriers to lung-directed gene therapy with recombinant adenoviruses. J. Virol. 69:2004-2015.

17. Jooss, K., and Chirmule, N. 2003. Immunity to adenovirus and adeno-associated viral vectors: implications for gene therapy. Gene Ther. 10:955-963.

18. Sette, A., and Fikes, J. 2003. Epitope-based vaccines: an update on epitope identification, vaccine design and delivery. Curr. Opin. Immunol. 15:461-470.

19. Crompton, J., Toogood, C.I., Wallis, N., and Hay, R.T. 1994. Expression of a foreign epitope on the surface of the adenovirus hexon. J. Gen. Virol. 75:133-139.

20. Yewdell, J.W., and Bennink, J.R. 1990. The binary logic of antigen processing and presentation to $\mathrm{T}$ cells. Cell. 62:203-206.

21. Gilleland, H.E., Hughes, E.E., Gilleland, L.B., Matthews-Greer, J.M., and Staczek, J. 1995. Use of synthetic peptides to identify surface-exposed, linear B-cell epitopes within outer membrane protein F of Pseudomonas aeruginosa. Curr. Microbiol. 31:279-286

22. Gilleland, H.E., et al. 2000. Chimeric animal and plant viruses expressing epitopes of outer membrane protein $\mathrm{F}$ as a combined vaccine against Pseudomonas aeruginosa lung infection. FEMS Immunol. Med. Microbiol. 27:291-297.

23. Gocke, K., et al. 2003. Mucosal vaccination with a recombinant OprF-I vaccine of Pseudomonas aeruginosa in healthy volunteers: comparison of a systemic vs. a mucosal booster schedule. FEMS Immunol. Med. Microbiol. 37:167-171.

24. Kim, D.K., et al. 2000. Comparison of two immunization schedules for a Pseudomonas aeruginosa outer membrane proteins vaccine in burn patients. Vaccine. 19:1274-1283.

25. Larbig, M., et al. 2001. Safety and immunogenicity of an intranasal Pseudomonas aeruginosa hybrid outer membrane protein F-I vaccine in human volunteers. Vaccine. 19:2291-2297.

26. Mansouri, E., et al. 1999. Safety and immunogenicity of a Pseudomonas aeruginosa hybrid outer membrane protein F-I vaccine in human volunteers. Infect. Immun. 67:1461-1470.

27. Matthews-Greer, J.M., and Gilleland, H.E. 1987. Outer membrane protein F (porin) preparation of Pseudomonas aeruginosa as a protective vaccine against heterologous immunotype strains in a burned mouse model. J. Infect. Dis. 155:1282-1291.

28. Moon, M.M., Hazlett, L.D., Hancock, R.E., Berk, R.S., and Barrett, R. 1988. Monoclonal antibodies provide protection against ocular Pseudomonas aeruginosa infection. Invest. Ophthalmol. Vis. Sci. 29:1277-1284.

29. Price, B.M., et al. 2002. Enhancement of the protective efficacy of an oprF DNA vaccine against Pseudomonas aeruginosa. FEMS Immunol. Med. Microbiol. 33:89-99.

30. Shenk, T. 1996. Adenoviridae: The viruses and their replication. In Fields Virology. B.N. Fields, D.M. Knipe, and P.M. Howley, editors. Lippincott-Raven Publishers Inc. Philadelphia, Pennsylvania, USA. 2111-2148.

31. Tang, J., et al. 2004. Adenovirus hexon T-cell epitope is recognized by most adults and is restricted by HLA DP4, the most common class II allele. Gene Ther. 11: 1408-1415.

32. Wohlfart, C. 1988. Neutralization of adenoviruses: kinetics, stoichiometry, and mechanisms. J. Virol. 62:2321-2328.

33. Youil, R., et al. 2002. Hexon gene switch strategy for the generation of chimeric recombinant adenovirus. Hum. Gene Ther. 13:311-320.

34. Brusic, V., Rudy, G., and Harrison, L.C. 1998. MHCPEP, a database of MHC-binding peptides: update 1997. Nucleic Acids Res. 26:368-371.

35. Nielsen, M., et al. 2004. Improved prediction of MHC class I and class II epitopes using a novel Gibbs sampling approach. Bioinformatics. 20:1388-1397.

36. Kikuchi, T., Worgall, S., Singh, R., Moore, M.A., and Crystal, R.G. 2000. Dendritic cells genetically modified to express CD40 ligand and pulsed with antigen can initiate antigen-specific humoral immunity independent of $\mathrm{CD} 4^{+} \mathrm{T}$ cells. Nat. Med. 6:1154-1159

37. Kikuchi, T., Hackett, N.R., and Crystal, R.G. 2001. Cross-strain protection against clinical and laboratory strains of Pseudomonas aeruginosa mediated by dendritic cells genetically modified to express CD40 ligand and pulsed with specific strains of Pseudomonas aeruginosa. Hum. Gene Ther. 12:1251-1263.

38. Worgall, S., et al. 2001. Protection against pulmonary infection with Pseudomonas aeruginosa following immunization with $P$. aeruginosa-pulsed dendritic cells. Infect. Immun. 69:4521-4527.

39. Porwoll, J.M., Gebel, H.M., Rodey, G.E., and Markham, R.B. 1983. In vitro response of human $\mathrm{T}$ cells to Pseudomonas aeruginosa. Infect. Immun. 40:670-674.

40. Bruderer, U., et al. 1992. Affinity constants of naturally acquired and vaccine-induced anti-Pseudomonas aeruginosa antibodies in healthy adults and cystic fibrosis patients. J. Infect. Dis. 166:344-349.

41. Dunkley, M.L., Clancy, R.L., and Cripps, A.W. 1994. A role for $\mathrm{CD} 4+\mathrm{T}$ cells from orally immunized rats in enhanced clearance of Pseudomonas aeruginosa from the lung. Immunology. 83:362-369.

42. Cripps, A.W., Dunkley, M.L., Clancy, R.L., and Kyd, J. 1995. Pulmonary immunity to Pseudomonas aeruginosa. Immunol. Cell Biol. 73:418-424.

43. Stevenson, M.M., Kondratieva, T.K., Apt, A.S., Tam, M.F., and Skamene, E. 1995. In vitro and in vivo T cell responses in mice during bronchopulmonary infection with mucoid Pseudomonas aeruginosa. Clin. Exp. Immunol. 99:98-105.

44. Stanislavsky, E.S., and Lam, J.S. 1997. Pseudomonas aeruginosa antigens as potential vaccines. FEMS Microbiol. Rev. 21:243-277.

45. Keogan, M.T., and Johansen, H.K. 2000. Vaccines for preventing infection with Pseudomonas aeruginosa in people with cystic fibrosis. Cochrane Database Syst. Rev. doi:10.1002/14651858.CD001399.

46. Pier, G.B. 2003. Promises and pitfalls of Pseudomonas aeruginosa lipopolysaccharide as a vaccine antigen. Carbohydr. Res. 338:2549-2556.

47. Benz, R., and Hancock, R.E. 1981. Properties of the large ion-permeable pores formed from protein $\mathrm{F}$ of Pseudomonas aeruginosa in lipid bilayer membranes. Biochim. Biophys. Acta. 646:298-308.

48. Yoshimura, F., Zalman, L.S., and Nikaido, H. 1983. Purification and properties of Pseudomonas aeruginosa porin. J. Biol. Chem. 258:2308-2314.

49. Mutharia, L.M., Nicas, T.I., and Hancock, R.E. 1982. Outer membrane proteins of Pseudomonas aeruginosa serotype strains. J. Infect. Dis. 146:770-779.

50. Mutharia, L.M., and Hancock, R.E. 1983. Surface localization of Pseudomonas aeruginosa outer membrane porin protein $\mathrm{F}$ by using monoclonal antibodies. Infect. Immun. 42:1027-1033.

51. Hancock, R.E., Mouat, E.C., and Speert, D.P. 1984. Quantitation and identification of antibodies to outer-membrane proteins of Pseudomonas aeruginosa in sera of patients with cystic fibrosis. J. Infect. Dis. 149:220-226.

52. Matthews, R.C., Burnie, J.P., and Tabaqchali, S. 1986. Immunoblot analysis of serological response to Pseudomonas aeruginosa septicaemia in man. J. Clin. Pathol. 39:1306-1312.

53. Staczek, J., et al. 1998. A chimeric influenza virus expressing an epitope of outer membrane protein $F$ of Pseudomonas aeruginosa affords protection against challenge with $P$. aeruginosa in a murine model of chronic pulmonary infection. Infect.
Immun. 66:3990-3994.

54. Chen, P.W., et al. 1996. Therapeutic antitumor response after immunization with a recombinant adenovirus encoding a model tumor-associated antigen. J. Immunol. 156:224-231.

55. Gurunathan, S., Klinman, D.M., and Seder, R.A. 2000. DNA vaccines: immunology, application, and optimization* [review]. Annu. Rev. Immunol. 18:927-974.

56. Randrianarison-Jewtoukoff, V., and Perricaudet, M. 1995. Recombinant adenoviruses as vaccines. Biologicals. 23:145-157.

57. Rubin, B.A. and Rorke, L.B. 1994. Adenovirus vaccine. In Vaccines. S.A. Plotkin and E.A. Mortimer, editors. The W.B. Saunders Co. Philadelphia, Pennsylvania, USA. 475-501.

58. Okada, N., et al. 2001. Efficient antigen gene transduction using Arg-Gly-Asp fiber-mutant adenovirus vectors can potentiate antitumor vaccine efficacy and maturation of murine dendritic cells. Cancer Res. 61:7913-7919.

59. Roberts, M.M., White, J.L., Grutter, M.G., and Burnett, R.M. 1986. Three-dimensional structure of the adenovirus major coat protein hexon. Science. 232:1148-1151.

60. Vigne, E., et al. 1999. RGD inclusion in the hexon monomer provides adenovirus type 5-based vectors with a fiber knob-independent pathway for infection. J. Virol. 73:5156-5161.

61. van Heeckeren, A.M., and Schluchter, M.D. 2002. Murine models of chronic Pseudomonas aeruginosa lung infection. Lab. Anim. 36:291-312.

62. Constant, S.L., and Bottomly, K. 1997. Induction of Th1 and Th2 CD4+ T cell responses: the alternative approaches. Annu. Rev Immunol. 15:297-322.

63. Rammensee, H., Bachmann, J., Emmerich, N.P., Bachor, O.A., and Stevanovic, S. 1999. SYFPEITHI: database for MHC ligands and peptide motifs. Immunogenetics. 50:213-219.

64. Reche, P.A., Glutting, J.P., Zhang, H., and Reinherz, E.L. 2004. Enhancement to the RANKPEP resource for the prediction of peptide binding to $\mathrm{MHC}$ molecules using profiles. Immunogenetics. 56:405-419.

65. Williams, K.M., Bigley, E.C., and Raybourne, R.B. 2000. Identification of murine B-cell and T-cell epitopes of Escherichia coli outer membrane protein $\mathrm{F}$ with synthetic polypeptides. Infect. Immun. 68:2535-2545

66. Zinkernagel, R.M. 2003. On natural and artificial vaccinations. Annu. Rev. Immunol. 21:515-546.

67. Hersh, J., Crystal, R.G., and Bewig, B. 1995. Modulation of gene expression after replication-deficient, recombinant adenovirus-mediated gene transfer by the product of a second adenovirus vector. Gene Ther. 2:124-131.

68. Mittereder, N., March, K.L., and Trapnell, B.C. 1996. Evaluation of the concentration and bioactivity of adenovirus vectors for gene therapy. J. Virol. 70:7498-7509.

69. Rosenfeld, M.A., et al. 1991. Adenovirus-mediated transfer of a recombinant alpha 1-antitrypsin gene to the lung epithelium in vivo. Science. 252:431-434.

70. Rosenfeld, M.A., et al. 1992. In vivo transfer of the human cystic fibrosis transmembrane conductance regulator gene to the airway epithelium. Cell. 68:143-155.

71. Stover, C.K., et al. 2000. Complete genome sequence of Pseudomonas aeruginosa PA01, an opportunistic pathogen. Nature. 406:959-964

72. Starke, J.R., Edwards, M.S., Langston, C., and Baker, C.J. 1987. A mouse model of chronic pulmonary infection with Pseudomonas aeruginosa and Pseudomonas cepacia. Pediatr. Res. 22:698-702.

73. Shand, G.H., Anwar, H., and Brown, M.R. 1988. Outer membrane proteins of polymyxin resistant Pseudomonas aeruginosa: effect of magnesium depletion. J. Antimicrob. Chemother. 22:811-821. 